\title{
Spatial stimulation of the electrosensory system of mormyrid electric fish
}

\author{
Patrick D Roberts ${ }^{1 *}$, Todd K Leen ${ }^{1}$, Nathaniel B Sawtell ${ }^{2}$, John Hunt ${ }^{1}$, Steven Case ${ }^{1}$ \\ From Nineteenth Annual Computational Neuroscience Meeting: CNS*2010 \\ San Antonio, TX, USA. 24-30 July 2010
}

The long-term goal of this project is to understand adaptive processing in sensory systems. Our work focuses on the electrosensory system of the mormyrid electric fish, a system uniquely suited for the study of adaptive sensory processing. The electrosensory lateral line lobe (ELL) of the mormyrid electric fish presents a special opportunity for examining the influence adaptation on sensory processing because much of the physiology [1] and anatomy [2] has been well characterized.

The mormyrid electric fish senses its environment by emitting an electric organ discharge (EOD) and detecting the perturbations that nearby objects cause in the self-generated electric field. Specialized mormyromast electroreceptors sense the self-generated field and its distortions. Afferent fibers from these electroreceptors respond to the fish's own EOD, and the field strength of the electric field is encoded in the latency of the afferent spike response $[3,4]$. The electrosensory responses are conveyed with somatotopic precision to the ELL where the fibers terminate [5].

Previous research on electrosensory adaptation has concentrated on point-like electrical fields on the skin. Since the purpose of the electrosensory system is to analyze changes in spatial patterns, we expect that presenting a spatially distributed electrical pattern will lead to a better understanding of adaptive aspects of electrosensory processing in ELL. Thus, we have begun construction of a stimulus device that can present a spatially distributed electrical pattern on the skin of a mormyrid fish. By controlling the patterns that we present, we can simultaneously record from principal cells of ELL to observe changes in responses to spatial patterns.

\footnotetext{
* Correspondence: contact_robertpa@ohsu.edu

'Biomedical Engineering, Oregon Health \& Science University, Portland, OR
} 97239, USA
The first phase of our stimulus development program has been to present a low-resolution, 1-dimensional pattern on the fish's skin. The design was based on an array of vertical rectangles that could be independently controlled to present a spatially varying electrical image along the fish's skin. We developed electrostatic models to predict fields that would be generated by an array of stimulator pads in water. We have developed an electrical pattern design algorithm that will approximate any given electrical pattern by imposing a set of electrical potentials on the stimulator array. The algorithm will allow flexibility in electrophysiological experimental design to test hypotheses about spatial effects on sensory processing.

A cellular modeling component of this study has been developed to predict the responses of individual neurons to stimulation by spatial patterns. Results of our neuronal network models will be compared with experimental measurements of cell responses to the same stimulation to iteratively improve our understanding of mechanisms of electrosensory processing.

\section{Author details}

'Biomedical Engineering, Oregon Health \& Science University, Portland, OR 97239, USA. ²Department of Neuroscience, Columbia University, New York, NY 10027, USA.

Published: 20 July 2010

\section{References}

1. Grant K, Sugawara Y, Gomes L, Han V, Bell CC: The Mormyrid electrosensory lobe in vitro: Physiology and pharmacology of cells and circuits. J Neurosci 1998, 18:6009-6025.

2. Meek j, Grant K, Bell CC: Structural organization of the mormyrid electrosensory lateral line lobe. J Exp Biol 1999, 202:1291-1300.

3. Sawtell NB, Williams A, Roberts PD, von der Emde G, Bell CC: Effects of sensing behavior on a latency code. J Neurosci 2006, 26(32):8221-34.

4. Szabo T, Hagiwara S: A latency-change mechanism involved in sensory coding of electric fish (mormyrids). Physiol Behav 1967, 2:331-335. 
5. Bell CC: Mormyromast electroreceptor organs and their afferent fibers in mormyrid fish. II. Intra-axonal recordings show initial stages of central processing. I Neurophysiol 1990, 63:303-318.

6. Sawtell NB, Williams A: Transformations of electrosensory encoding associated with an adaptive filter. J Neurosci 2008, 28(7):1598.

doi:10.1186/1471-2202-11-S1-P64

Cite this article as: Roberts et al: Spatial stimulation of the

electrosensory system of mormyrid electric fish. BMC Neuroscience 2010

11(Suppl 1):P64.

Submit your next manuscript to BioMed Central and take full advantage of:

- Convenient online submission

- Thorough peer review

- No space constraints or color figure charges

- Immediate publication on acceptance

- Inclusion in PubMed, CAS, Scopus and Google Scholar

- Research which is freely available for redistribution

Submit your manuscript at www.biomedcentral.com/submit

O) BioMed Central 